\title{
DINAMIKA KEHIDUPAN EKONOMI PETANI GARAM DI DESA DRESI KULON
}

\author{
Akhriyadi Sofian ${ }^{1 *}$, Nur Yanti ${ }^{1}$, Naili Ni'matul Illiyyun ${ }^{1}$ \\ ${ }^{1}$ Universitas Islam Negeri Walisongo, Indonesia \\ *e-mail: akhriyadi.sofian@walisongo.ac.id
}

\begin{abstract}
Abstrak
Garam merupakan komoditas yang selalu dibutuhkan oleh masyarakat baik untuk konsumsi maupun industri. Permintaan garam yang tinggi di pasar membuat produsen garam harus bisa memenuhi kebutuhan akan komoditas ini. Desa Dresi Kulon Kecamatan Kaliori merupakan salah satu daerah yang memproduksi garam. Mayoritas masyarakat Desa Dresi Kulon merupakan petani garam. Penelitian ini bertujuan untuk mengetahui dinamika apa yang terjadi dalam kehidupan petani garam tradisional di Desa Dresi Kulon dan bagaimana strategi yang dilakukan oleh petani garam untuk memenuhi kebutuhan ekonominya. Penelitian ini merupakan penelitian kualitatif dengan pendekatan deskriptif analitis. Data didapatkan dengan cara observasi partisipatoris, wawancara mendalam, dan dokumentasi. Hasil dari penelitian ini menunjukkan bahwa adanya kendala yang dialami oleh petani garam meliputi perubahan cuaca, banyaknya impor garam, dan menurunnya harga garam karena hasil garam yang melimpah. Adanya berbagai kendala dalam memproduksi garam memaksa petani garam harus beralih profesi melakukan pekerjaan sampingan menjadi nelayan, petani sawah, dan tukang ojek. Selain itu, mereka juga memanfaatkan relasi atau jaringan, alternatif subsistensi, dan mengikat sabuk lebih kencang. Petani garam di Desa Dresi Kulon menggunakan prinsip mekanisme survival yang merupakan bagian dari teori moral ekonomi petani yang dikemukakan oleh James C. Scott. Hal tersebut merupakan bentuk dari strategi yang dilakukan oleh petani garam agar tetap survive dalam menghadapi kendala yang terjadi selama produksi garam.
\end{abstract}

Kata kunci: Garam; Petani Garam; Mekanisme Survival; Subsisten

\begin{abstract}
Salt is one of the commodities that people desperately need both for consumption and industry. The high demand for salt in the market makes salt producers need to meet the need for this commodity. Dresi Kulon Kemacamatan Kaliori village is one of the areas that produce salt. The majority of the people there are salt farmers. This research is a qualitative study with a descriptive-analytical approach. In this study, data collection techniques were conducted by observation, interview, and documentation. This research aims to find out the dynamics of what happens in the life of traditional salt farmers in Dresi Kulon Village and how salt peasants carry out the strategy to fulfill their economic needs. The results of this study show that there are obstacles experienced by salt peasants, such as changes in the weather, the number of salt imports, and the decrease in salt prices because of abundant salt yields. Salt peasants were forced to switch professions to survive in their lives. Salt peasants do side jobs such as fishermen, peasants, and motorcycle taxi drivers. They also use relationships and social networks, subsistence alternatives, and fastening belts. Salt peasants in Dresi Kulon Village use the principle of survival mechanisms that are part of the moral economic theory of farmers put forward by James C. Scott. This is a form of the strategy used by salt peasants to survive in the face of obstacles during salt production.
\end{abstract}

Keywords: Salt; Salt Peasant; Survival Mechanism; Subsistence

This is an open access article under the CC BY-SA license.

Copyright (C) 2021 by Author. Published by Universitas Pendidikan Ganesha.

\section{PENDAHULUAN}

Garam selalu dibutuhkan dalam kehidupan sehari-hari. Manusia memanfaatkan garam untuk dikonsumsi sekaligus untuk kepentingan industri. Di Indonesia garam umumnya diproduksi dengan cara menguapkan air laut pada sebidang tanah pantai dengan bantuan angin dan sinar matahari sebagai sumber energi penguapan. Biasanya wilayah pesisir menjadi tempat untuk memproduksi garam. Meskipun demikian, Widarto dalam (Farahdina, 
2016) mengungkap bahwa tidak semua wilayah pesisir cocok sebagai tempat produksi garam.

Salah satu daerah penghasil garam di Indonesia ialah Kabupaten Rembang, tepatnya di Desa Dresi Kulon, Kecamatan Kaliori. Produksi garam oleh petani garam di Rembang masih menggunakan cara tradisional yang bergantung pada musim (cuaca panas). Kondisi iklim dan cuaca yang seringkali berubah membuat hasil produksi garamnya menjadi rendah (Syafi'i, 2006).

Petani garam di Dresi Kulon menggarap tambak garam yang ada di tepi pantai. Waktu yang paling baik untuk mengusahakan garam pada musim kemarau, dari bulan Juni sampai Agustus. Jumlah petani garam yang menggarap tambak berbeda-beda setiap tambak, biasanya satu hektare tambak dapat digarap oleh dua sampai lima orang petani. Untuk membuat garam memerlukan waktu kurang lebih tiga sampai tujuh hari. Proses pembuatan garam bisa lebih cepat jika cuaca panas, sebaliknya jika cuaca berubah-ubah maka memakan waktu lebih lama.

Garam yang dihasilkan oleh petani garam di Desa Dresi Kulon adalah jenis garam krosok ${ }^{1}$. Pada waktu panen petani garam diupah dengan bagen². Garam yang dihasilkan biasanya dijual oleh pemilik tambak ke tengkulak. Penggarap tambak tidak ikut andil dalam proses jual beli garam, mereka hanya menerima hasil yang diberikan oleh pemilik tambak. Petani garam akan mendapat upah dari pemilik tambak ketika hasil panennya sudah terjual (Nikmaturohmah, 2016).

Petani garam dihadapkan pada persoalan struktural baik di tingkat petani (produsen), pasar, maupun pada kebijakan pemerintah. Pada tingkat petani garam, petani dihadapkan pada masalah sistem bagi hasil yang dirasa

\footnotetext{
1 Garam mentah yang tidak beriodium

2 Sistem bagi hasil yang dilakukan oleh penggrap tambak dengan pemilik tambak yang pada umumnya sebesar $50 \%$.
}

tidak adil karena semua keputusan tergantung pada pemilik lahan. Kemudian struktur pasar garam yang juga bersifat monopolistik, sehingga dikuasai oleh pemilik modal atau tengkulak. Selain itu perlindungan terhadap petani garam belum dilakukan dengan baik yang menyebabkan petani garam mampu untuk mempertahankan dan mengembangkan usaha penggaraman (Andriyani, 2013). Adanya anomali cuaca juga menjadi kendala tersendiri dalam produksi garam. Dalam kondisi sebagaimana di atas petani garam di Desa Dresi Kulon melakukan beberapa pekerjaan sampingan untuk memperoleh penghasilan dan memenuhi kebutuhan hidupnya.

Ekonomi yang sempit menyebabkan para petani garam memilih cara-cara yang aman dalam memenuhi subsistensinya. Keamanan subsistensi merupakan prinsip yang lebih aktif dalam pilihan dan tata nilai petani daripada pemaksimalan hasil rata-rata, yang kemudian para petani khususnya petani kecil memiliki prinsip "dahulukan selamat" atau safety-first. Prinsip tersebut merupakan cara-cara klasik yang dilakukan oleh para petani untuk menghindari risiko yang tidak perlu, penurunan sedikit saja terhadap produksi dapat berpengaruh besar bagi kelangsungan hidup rumah tangga mereka. Para petani enggan mengambil resiko dan lebih memusatkan diri pada usaha untuk menghindari jatuhnya hasil produksi, bukan pada usaha memaksimumkan keuntungan-keuntungan harapan (Scott, 1983). Berdasarkan pada latar belakang di atas, rumusan masalah dalam penelitian ini adalah: (a) Bagaimana dinamika kehidupan ekonomi petani garam tradisional di Desa Dresi Kulon Kecamatan Kaliori Kabupaten Rembang? (b) Bagaimana strategi pemenuhan kebutuhan ekonomi petani garam tradisional di Desa Dresi Kulon Kecamatan Kaliori Kabupaten Rembang?

Sangat menarik bagaimana Yetty Rochwulaningsih mengulas 
mengenai posisi strategis komoditas garam di Indonesia dari perspektif sejarah. Dari artikel ini kita bisa mafhum mengenai kompleksitas komoditas garam yang tidak banyak memberi keuntungan kepada petani garam selepas era kolonial karena tidak adanya regulasi atau kebijakan pemerintah yang memproteksi industri garam dalam negeri (Rochwulaningsih, 2012) . Tidak adanya proteksi dari pemerintah juga diungkap yang menempatkan para petani garam menjadi subordinat para penguasa dan pemilik modal. Petani garam menjadi sangat bergantung pada pemilik modal yang notabene berpengaruh pada kesejahteraan petani garam (Rochwulaningsih, 2007). Pemilik modal dalam industri garam tradisional memiliki pengaruh yang sangat signifikan terhadap kesejahteran petani garam (Zakki N. d., 2016).

Artikel karya Ichsanuddin, dkk (2016) dan Dheddy Pri Haryanto (2012) memiliki benang merah yang sama dalam membahas mengenai strategi yang dilakukan oleh petani garam dalam menggarap tambak garam. Petani garam diharuskan untuk beradaptasi dengan segala kendala dalam menggarap tambak garam. Tulisan ini juga hendak membahas berbagai kendala yang dialami oleh petani garam terutama perubahan cuaca dan harga garam yang selalu turun di pasaran. Petani garam di Dresi Kulon menerapkan berbagai strategi untuk bertahan hidup mulai dari melakoni pekerjaan sampingan, menghemat, hingga memanfaatkan relasi patron-klientelistik dengan tengkulak.

Untuk dapat mempertahankan subsistensinya petani harus memiliki strategi untuk mempertahankan hidup, Scott menamakanya mekanisme survival, sebagaimana diuraikan oleh Baiquni (2007) sebagai berikut, yaitu: pertama memanfaatkan relasi atau jaringan sosial. Petani sangat lumrah meminta bantuan kepada sanak saudara, teman sedesa, tetangga atau memanfaatkan hubungan dengan pelindungnya (patron), yang mana ikatan antara patron dan klien merupakan salah satu bentuk asuransi di kalangan petani. Menariknya di Desa Dresi Kulon relasi patron klien tidak hanya terlihat pada relasi antara pemilik tambak dengan petani garam, juga antara tengkulak dengan petani garam. Kedua, alternatif subsistensi yakni usaha swadaya yang digeluti oleh petani seperti berjualan kecil-kecilan, bekerja sebagai tukang, sebagai buruh lepas, berternak, atau melakukan migrasi untuk mencari pekerjaan. Umumnya petani garam yang ada di Desa Dresi Kulon memiliki pekerjaan sampingan sebagai alternatif lain yang dapat dilakukan sebagai penunjang perekonomian mereka agar tetap dapat mempertahankan hidupnya. Ketiga, mengikat sabuk lebih kencang ialah cara yang dilakukan oleh petani garam menekan pengeluaran mereka agar tetap bertahan hidup. Petani garam yang memiliki sawah atau kebun dapat memanfaatkan hasil kebun atau sawah yang mereka miliki untuk dapat memenuhi kebutuhan pangan mereka.

\section{METODE}

Penelitian ini menggunakan metode penelitian kualitatif dengan pendekatan deskriptif analitis. Data primer dalam penelitian ini diperoleh langsung melalui hasil observasi dan wawancara mendalam dengan cara menggali dari sumber informasi (informan kunci) dan dari catatan lapangan yang relevan dengan masalah yang diteliti. Pemilihan informan berdasar pada kesesuaian dengan tema penelitian sehingga dipilih tiga orang informan utama yang merupakan petani garam (penggarap) yang tidak memiliki tambak, dan dua pemilik tambak sebagai informan pendukung. Para informan tersebut mampu memberikan informasi yang komprehensif mengenai dinamika kehidupan petani garam, proses penggarapan tambak garam, dan termasuk relasi strukural antara petani garam dengan pemilik tambak garam. 
Analisis data dalam penelitian ini menggunakan analisis data yang dikembangkan oleh Miles, et al. Analisis data menurut Miles, et al (2014) merupakan rangkaian aktivitas yang berlangsung secara bersamaan dalam tiga tahap: tahap kondensasi data (data condensation), tahap penyajian data (data display), dan penarikan kesimpulan atau verifikasi (conclusion drawing/verification). Tahap kondensasi data ini meliputi proses pengumpulan, simplikasi, abstraksi, dan transformasi data, baik yang merupakan catatan lapangan, transkrip wawancara, dokumen, ataupun bahanbahan empiris yang lainnya. Tahap penyajian data merupakan proses pengaturan, pemadatan informasi yang akan disajikan dalam sebuah tulisan (teks). Sedang tahap penarikan kesimpulan (verifikasi) adalah proses interpretasi yang dilakukan oleh peneliti dengan mencatat berbagai pola, penjelasan, dan berbagai proposisi. Selain itu makna-makna yang sangat mungkin muncul dari data harus diuji validitasnya.

\section{HASIL DAN PEMBAHASAN Proses Pembuatan Garam di Desa Dresi Kulon}

Ketika musim kemarau para petani di Desa Dresi Kulon mulai menggarap tambak garam yang ada di Desa mereka. Para petani garam biasanya bekerja dari jam tujuh pagi sampai jam empat sore, akan tetapi petani tidak dituntut untuk selalu berada di tambak, karena pekerjaan petani garam yang fleksibel, jika pekerjaannya dirasa sudah selesai petani bisa pulang meskipun belum sore. Biasanya setelah proses penataan tambak selesai petani garam sesekali ke tambak untuk melihat garam yang sedang dikeringkan apakah sudah siap panen atau belum.

Pada proses pembuatan garam terdapat dua cara yang dilakukan oleh petani garam yang ada di Desa Dresi Kulon yaitu secara tradisional dengan peralatan yang masih sederhana atau manual dan secara modern dengan menggunakan mesin atau peralatan canggih. Namun, mayoritas petani garam yang ada di Desa Dresi Kulon masih menggunakan alat-alat yang tradisional atau manual. Berikut gambar beberapa alat yang dipakai membuat garam secara tradisional di Desa Dresi Kulon.

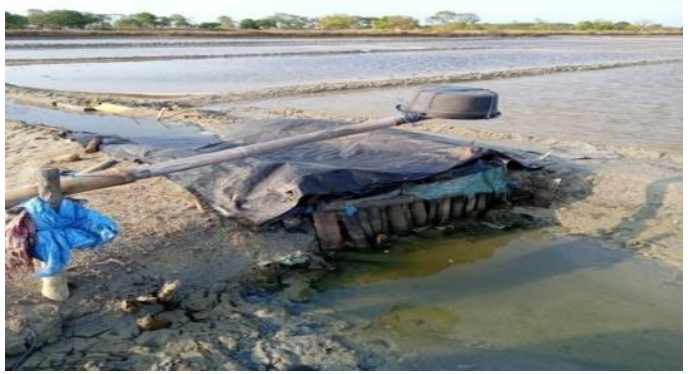

Gambar 1. Eboran, digunakan untuk memindahkan air dari caren ke tambak

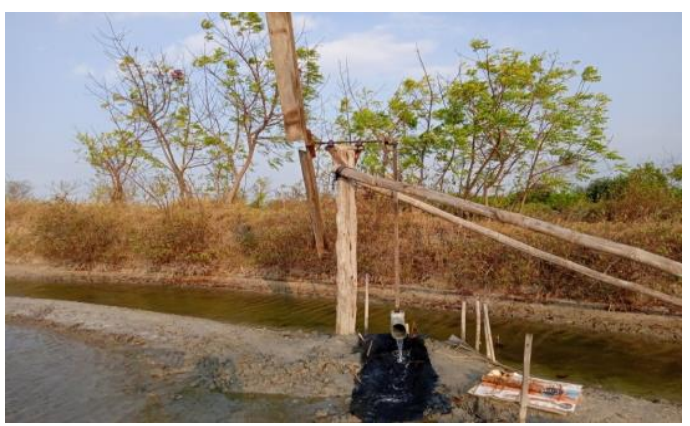

Gambar 2. Kincir angin, digunakan untuk mengalirkan air laut ke caren

Proses pembuatan garam baik secara tradisional maupun modern hampir sama, bedanya waktu yang diperlukan lebih cepat jika menggunakan alat yang sudah modern dibanding dengan menggunakan alat yang masih tradisional. Pembuatan garam dengan menggunakan alat yang masih tradisional para petani garam harus menghaluskan lahan terlebih dahulu. Sedang jika menggunakan alat yang modern para petani garam hanya perlu memadatkan saja lahannya tanpa harus menghaluskan, karena para petani menggunakan geoisolator yaitu alat berupa mejanan plastik. Adapun langkah-langkah yang dilakukan 
selanjutnya sama dengan proes pembuatan garam secara tradisional.

\section{Proses Produksi Garam secara Tradisional}

Proses ini dilakukan dengan tata urut sebagai berikut:

1) Pembenahan lahan

Pada proses pembuatan garam secara tradisional diawali dengan membenahi lahan terlebih dahulu sebelum diisi air karena sebelumnya tambak garam biasanya digunakan sebagai tambak ikan. Pembenahan dilakukan dengan cara mengeringkan lahan kemudian memadatkan lahan menggunakan slender ${ }^{3}$, dan dihaluskan menggunakan usut'. Tujuannya agar lahannya menjadi padat sehingga ketika diisi dengan air laut tidak merembes. Pembenahan lahan sendiri dibutuhkan waktu satu hari sampai tiga hari baru dapat diisi air laut.

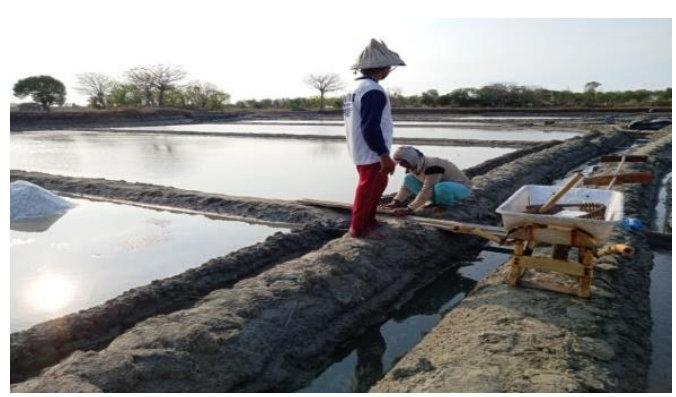

Gambar 3. Membenahi lahan tambak

2) Memindahkan air ke lahan tambak Sambil menunggu lahan penggaraman itu ditata, air laut yang sudah diambil akan dialirkan ke caren ${ }^{5}$ menggunakan kincir angin, yang kemudian akan ditampung terlebih dahulu di caren yang ada di dekat tambak dan ditunggu sampai umur air lautnya itu tua.

Adapun cara untuk mengetahui umur air laut yang ada di penampungan itu sudah tua atau belum para petani garam menggunakan ukuran air yaitu alat yang digunakan untuk mengetahui

\footnotetext{
3 Alat untuk memadatkan tanah

4 Alat untuk menghaluskan lahan

5 Tempat penampungan air laut yang sudah tua
}

umur air laut ${ }^{6}$. Setelah lahannya selesai ditata baru dapat dialiri air yang ada di caren (penampungan air) dengan menggunakan eboran ${ }^{7}$. Air laut yang umurnya sudah tua akan dialirkan ke lahan yang kering, setelah itu ditunggu sampai menjadi garam. Proses pembuatan garam sendiri memerlukan waktu kurang lebih 20 hari dari mulai membenahi lahan sampai panen jika cuacanya itu panas, jika ada kendala seperti hujan maka waktu yang diperlukannya pun lebih lama.

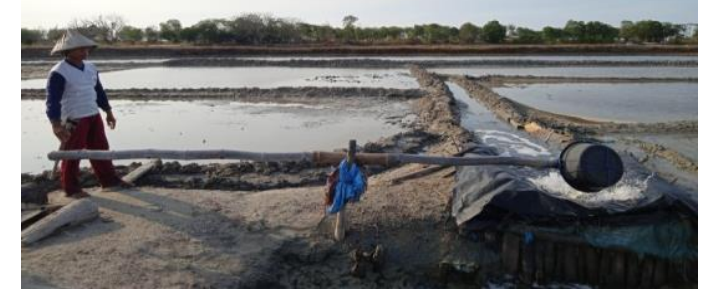

Gambar 4. Memindahkan air yang sudah tua ke lahan tambak

\section{3) Memanen garam}

Setelah air laut yang berada di tambak sudah berubah menjadi kristalkristal, garam-garam tersebut sudah dapat dipanen. Garam yang sudah dipanen akan dimasukkan ke gudang garam terlebih dahulu sebelum nantinya dijual kepada tengkulak. Petani sendiri memanen garam dengan menggunakan serok dan juga ekrak dan diangkut menggunakan angkong.

\footnotetext{
${ }^{6}$ Umur air laut yang sudah tua jika pada alat pengukur kadar garam sudah menunjukkan angka 20

7 Alat seperti gayung yang digunakan untuk mengalirkan air ke lahan
} 


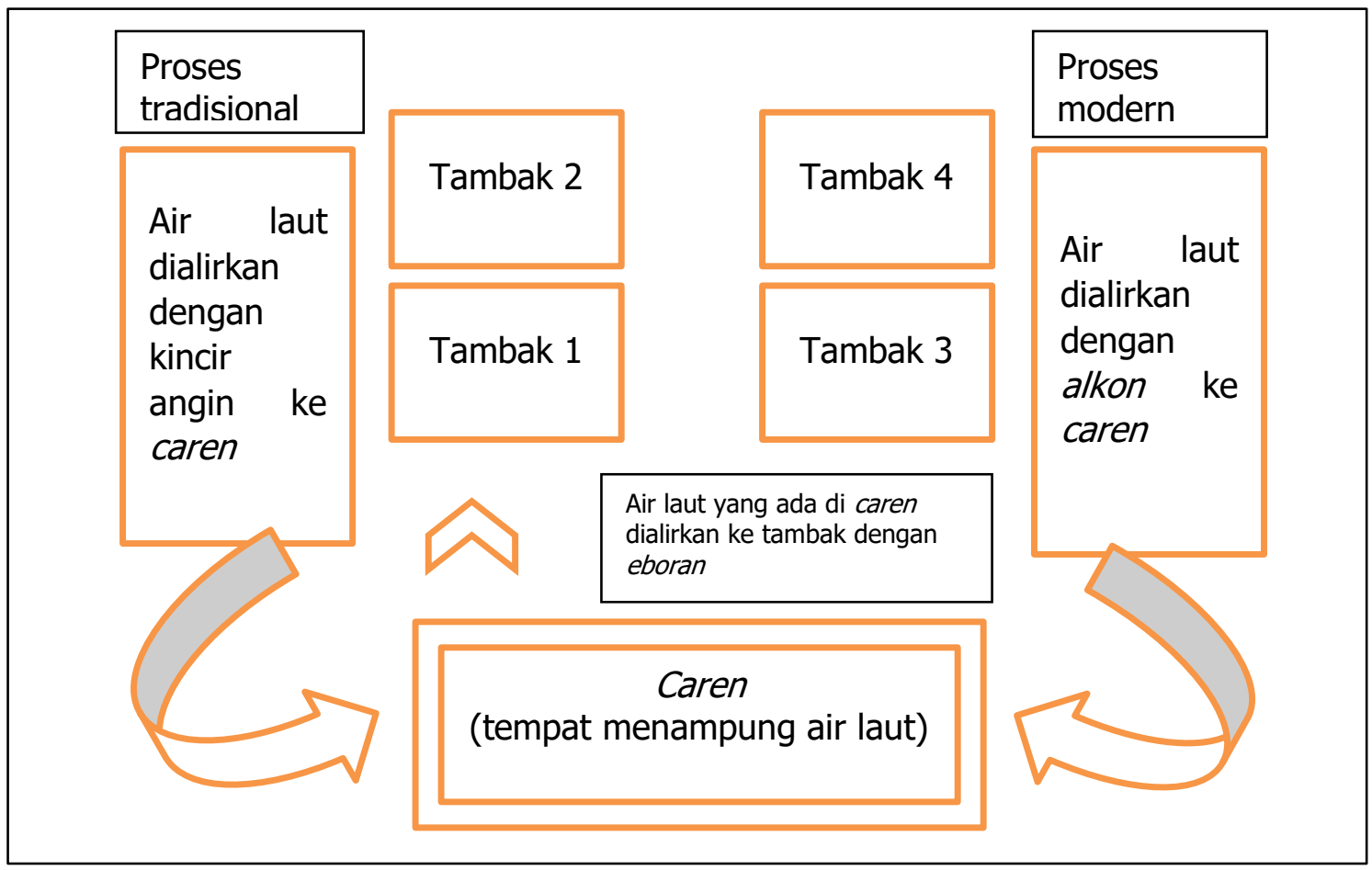

Gambar 5. Skema pembuatan garam

Proses produksi garam secara modern

Perbedaan pembuatan garam secara tradisional dengan yang sudah modern terletak pada alat-alat yang digunakannya. Peralatan menjadi sangat penting dan sangat dibutuhkan dalam proses produksi garam, karena dengan adanya peralatan yang digunakan oleh para petani dapat membantu pekerjaan petani dalam hal produksi garam. Meskipun alat-alat yang digunakan oleh para petani garam itu berbeda, tradisional ataupun modern, namun keduanya memiliki fungsi yang sama. Jika pembuatan garam secara tradisional para petani garam masih menggunakan mejanan tanah sebagai media kristalisasi. Adapun alat-alat modern yang digunakan untuk membuat garam, ialah: a) geoisolator atau geomembran, yaitu mejanan plastik sejenis terpal sebagai media pembuatan garam atau meja kristalisasi, b) alkon, merupakan penyedot air yang digunakan untuk mengalirkan air laut ke tambak.

Namun tidak semua petani garam yang ada di Desa Dresi Kulon menggunakan geoisolator . Garam yang dibuat dengan menggunakan alat geoisolator hasil garamnya itu putih, bersih dan halus. Adanya perbedaan alat yang digunakan oleh para petani juga berpengaruh pada modal yang dikeluarkan untuk biaya akomodasi peralatan yang digunakan. Oleh karena itu terdapat beberapa pemilik tambak yang rela mengeluarkan modal yang cukup banyak untuk proses produksi garam agar dapat meningkatkan hasil produksinya. Biaya yang dikeluarkan lebih banyak jika menggunakan alat yang sudah modern karena alat-alat yang digunakannya pun mahal, misalnya saja seperti alat geoisolator yang jika beli harganya sekitar $\mathrm{Rp}$ 2.800.000 per 50 meter, belum lagi biaya yang digunakan guna membeli bahan bakar untuk alat penyedot air seperti alkon. Perubahan zaman membuat semakin berkembangnya teknologi sehingga mendorong beberapa produsen garam menggunakan alat-alat produksi garam yang sudah modern dengan tujuan untuk efisiensi dan meningkatkan hasil produksi garam mereka walaupun modal yang dikeluarkan banyak. 
Bagan gambaran proses modern seperti terlihat pada Tabel 1. produsi garam baik tradisional ataupun

Tabel 1. Proses pembuatan garam

\begin{tabular}{|c|c|c|}
\hline Proses pembuatan garam & Tradisional & Modern \\
\hline $\begin{array}{c}\text { Tahap-tahap pembuatan } \\
\text { garam }\end{array}$ & $\begin{array}{l}\text { a. Pembenahan lahan } \\
\text { b. Memindahkan air laut } k \\
\text { c. Memanen garam }\end{array}$ & ahan tambak \\
\hline \multirow{2}{*}{ Alat untuk membuat garam } & \multicolumn{2}{|c|}{$\begin{array}{l}\text { a. Slender, alat yang digunakan untuk mengeringkan } \\
\text { dan memadatkan lahan } \\
\text { b. Usut, alat untuk menghaluskan lahan } \\
\text { c. Caren, tempat penampungan air laut yang sudah tua } \\
\text { d. Kincir, alat untuk mengalirkan air laut ke caren } \\
\text { e. Eboran, alat serupa gayung untuk mengalirkan air laut } \\
\text { ke lahan } \\
\text { f. Serok/ekrak, alat untuk memanen garam } \\
\text { g. Angkong, alat untuk mengangkut garam }\end{array}$} \\
\hline & $\begin{array}{ll}\text { a. } & \text { Mejanan tanah: alat } \\
\text { untuk membuat garam } \\
\text { b. Kincir angin: alat } \\
\text { untuk menyedot air } \\
\text { laut dan mengalirkan } \\
\text { ke tambak }\end{array}$ & $\begin{array}{l}\text { a. Geoisolator } \\
\text { (geomembran): } \\
\text { Mejanan plastik sejenis } \\
\text { terpal sebagai media } \\
\text { pembuatan garam } \\
\text { b. Alkon: alat untuk } \\
\text { menyedot air laut agar } \\
\text { air laut mengalir ke } \\
\text { tambak }\end{array}$ \\
\hline
\end{tabular}

\section{Kendala-Kendala Yang Dialami Petani Garam Dalam Menggarap Tambak}

Kendala yang dialami oleh petani garam merupakan resiko dalam proses pembuatan garam. Adapun masalah atau kendala yang dialami oleh hampir semua petani garam sebagai berikut.

\section{Perubahan cuaca}

Proses pembuatan garam itu sangat bergantung pada cuaca panas, sehingga ketika hujan itu menjadi problem tersendiri bagi para petani garam. Hal tersebut juga dijelaskan oleh Haryatno (2012) yang menyebut bahwa cuaca yang tidak menentu mengganggu kelancaran proses produksi garam yang dilakukan oleh petani garam. Air laut yang umurnya sudah tua dan siap untuk dijemur jika terkena air hujan, maka otomatis umurnya akan kembali muda lagi, sehingga membutuhkan waktu yang semakin lama untuk bisa dibuat menjadi garam, karena harus menunggu air laut itu umurnya menjadi tua kembali baru bisa dipindahkan ke petakan yang kering untuk dijemur. Seperti pernyataan yang disampaikan oleh SD seorang petani garam:

"Kendalane ya nak pas hujan niku mbak, soale sing harus e wes iso panen dadi rak iso mergo uyah e mbalek nom meneh mbak, dadi ya mulai soko awal meneh mbak, dadi wektune tambah suwi mbak"

(Kendalanya ya kalau pas hujan itu mbak, soalnya yang harusnya sudah bisa panen jadi nggak bisa karena garamnya kembali muda lagi mbak, jadi ya harus mulai dari awal lagi, jadi waktunya tambah lama mbak) (SD, 58 tahun, Wawancara pribadi, Kamis 7 Mei 2020).

Jika bagi petani padi hujan itu merupakan musim yang ditunggu namun sebaliknya bagi para petani garam dengan adanya hujan membuat proses pembuatan garam menjadi terhambat. Perubahan iklim sangat mempengaruhi hasil panen yang kemungkinan besar akan berkurang. Dengan berkurangnya hasil panen niscaya mengancam ketahanan pangan para petani garam (Chiari, 2015). Jika musim hujan berlangsung 
lama maka petani garam tidak memperoleh pendapatan untuk memenuhi kebutuhan hidup mereka.

Kondisi cuaca yang tidak menentu menyebabkan petani garam untuk beradaptasi dengan berbagai strategi agar mereka tetap memperoleh penghasilan untuk memenuhi kebutuhan hidup mereka. Sebagaimana dijelaskan oleh Mazali dalam Haryatno (2012) bahwa strategi adaptasi merupakan perilaku manusia dalam mengalokasikan sumberdaya yang mereka miliki untuk menghadapi masalah-masalah yang dimanfaatkan sebagai pilihan tindakan yang tepat dan sesuai dengan lingkungan sosial, kultural, ekonomi, dan ekologis di tempat dimana mereka hidup.

Petani garam yang masih memiliki tanah atau sawah lantas bekerja menggarap sawah miliknya. Seperti yang dilakukan oleh JD, ketika musim hujan ia akan menggarap sawah yang ia miliki dan ketika musim kemarau tiba ia kembali bekerja menggarap tambak garam. Pendapatan yang diperoleh JD dari hasil panen sawah tersebut sebagian disimpan dan digunakan sewaktu musim paceklik tidak bisa bekerja menggarap tambak garam.

Berbeda dengan petani garam yang tidak memiliki sawah, biasanya mereka mencari pekerjaan lain seperti tukang ojek dan nelayan. Hal tersebut merupakan bentuk dari cara petani garam di Dresi Kulon untuk memenuhi subsistensinya, sehingga petani garam lebih memilih cara-cara yang aman untuk memenuhi subsistensinya dibandingkan harus memaksimalkan keuntungan yang mana dapat dikatakan dengan "dahulukan selamat" atau safety-first. Prinsip tersebut merupakan cara klasik yang dilakukan oleh para petani untuk menghindari resiko yang tidak perlu (Scott, 1983). Cara-cara aman yang dilakukan oleh petani garam di Desa Dresi Kulon yaitu dengan beralih profesi atau mencari pekerjaan sampingan. Hal tersebut dilakukan oleh para petani garam untuk tetap dapat memperoleh pendapatan guna mempertahankan hidupnya ketika para petani sedang tidak memproduksi garam karena adanya perubahan cuaca. Selain mengerjakan sawahnya pekerjaan sampingan yang dilakukan oleh para petani garam yakni menjadi tukang ojek seperti yang dilakukan oleh JN (47 tahun):

\section{"Kerjaane kulo selain nggarap tambak nggih mok ngojek niku mbak"}

(Kerjaan saya selain menggarap tambak ya hanya ngojek itu mbak) (JN, 47 tahun, Wawancara pribadi, Rabu 22 April 2020)

Menurut pengakuannya JN melakukan pekerjaan sebagai tukang ojek ketika malam hari karena pada waktu pagi dan sore hari JN berada di tambak untuk menggarap tambak. Meskipun pendapatan yang diterima JN dari ojek tidak seberapa namun cukup untuk memenuhi subsistensinya seharihari daripada harus menunggu penghasilan dari panen garam. Selain JN yang mempunyai pekerjaan sampingan sebagai tukang ojek, ada juga RD (55 tahun) yang memiliki pekerjaan sampingan sebagai nelayan. Dia memilih pekerjaan sampingan sebagai nelayan, mencari kepiting di laut, ketika malam hari sesudah bekerja di tambak garam. Dari hasil tangkapan yang diperoleh $R D$ selanjutnya dijual untuk membantu menambah pendapatannya guna memenuhi kebutuhan hidup sehari-harinya.

Dalam kaitannya dengan etika subsistensi Scott (1983) menyebut bahwa untuk memenuhi kebutuhan subsistensinya petani beralih profesi atau mencari pekerjaan sampingan. Alternatif subsistensi merupakan salah satu bagian dari strategi mekanisme survival yang dikemukakan oleh Scott, dimana menurut Scott petani dapat menggunakan alternatif subsistensi dengan usaha-usaha swadaya seperti berjualan kecil-kecilan, beralih profesi, atau melakukan migrasi (Rizaldi A. , 2017). Ritzer dalam Masruroh dan Mauliadi (2020) juga mengungkapkan bahwa individu ataupun kelompok 
niscaya memiliki kecenderungan untuk bertahan dari kondisi ataupun situasi yang tidak menguntungkan dengan mempraktikkan mekanisme survival atau strategi bertahan hidup. Hal tersebut juga dilakukan oleh para petani garam di Desa Dresi Kulon dimana para petani garam memilih untuk beralih profesi atau mencari pekerjaan sampingan. Sehingga ketika para petani garam belum memperoleh pendapatan dari produksi garam, setidaknya mereka masih memperoleh pendapatan dari pekerjaan lain untuk memenuhi kebutuhan hidupnya.

\section{Adanya impor garam}

Produsen garam rakyat hanya dapat memenuhi kebutuhan garam untuk kepentingan konsumsi, sehingga pemerintah melakukan impor garam untuk tetap dapat memenuhi kebutuhan garam industri. Rochwulaningsih (2012) juga menjelaskan jika adanya kebijakan impor garam dapat menjadi indikator yang kuat akan keterpurukan garam rakyat sebagai komoditas strategis. Kebijakan impor garam ditempuh pemerintah karena produksi garam rakyat tidak dapat memasok kebutuhan di pasaran baik secara kualitas maupun kuantitasnya.

Menurut Fauzin (2019)

masuknya impor garam pada tahun 2017 mencapai 2,5 juta ton, dan mengalami peningkatan menjadi 3,7 juta ton pada tahun 2018. Sedang pada tahun 2019 sebesar 2,7 juta ton. Meskipun hasil garam yang diproduksi oleh para petani melimpah namun hasil garam tersebut belum mampu memenuhi kebutuhan industri. Garam untuk industri disebut memiliki syarat atau ketentuan khusus yang tidak dimiliki oleh garam lokal, sehingga untuk memenuhi kebutuhan industri tidak cukup jika hanya menggunakan garam lokal dalam negeri.

Sungguh ironis memang mengetahui Indonesia sebagai negara maritim akan tetapi masih mengimpor garam dari negara lain. Terkait dengan itu Salim dan Munadi (2016) menjelaskan bahwa ada beberapa faktor yang membedakan antara produksi garam lokal dengan luar negeri. Pertama, produktivitas garam lokal yang masih sangat rendah hanya sebesar 60 sampai 70 ton per hektare. Jumlah tersebut jauh lebih rendah jika dibandingkan dengan Australia yang mampu menghasilkan garam sampai 350 ton per hektare.

Kedua, teknik produksi serta peralatan yang digunakan yang berbeda dengan Australia. Produksi garam di Indonesia umumnya masih secara tradisional dan manual yang sangat bergantung pada cuaca hanya. Kondisi ini memungkinkan dapat memproduksi garam hanya dalam waktu 4 bulan saja. Sedang Australia memiliki masa produksi lebih panjang hingga 8 bulan, sehingga tidak heran dapat menghasilkan garam yang jauh lebih banyak dengan kualitas yang tinggi. Ketiga, produksi garam lokal memiliki kualitas rendah yang belum memenuhi persyaratan yang diinginkan oleh industri.

Impor garam menjadi kendala serius yang membuat garam lokal mengalami surplus dan dapat merugikan para pelaku usaha garam karena mengakibatkan rendahnya harga garam lokal. Sedang pendapatan yang diterima petani garam sendiri itu bergantung pada penghasilan dari penjualan hasil panen. Sehingga jika adanya penurunan harga jual garam lokal akibat kalah bersaing dengan garam impor niscaya sangat berdampak pada rendahnya penghasilan yang diperoleh petani garam.

\section{Strategi Petani Garam dalam Pemenuhan Kebutuhan Ekonomi}

James Scott menyatakan bahwa moral ekonomi petani didasarkan atas norma subsistensi dan norma resiprositas. Norma subsistensi timbul ketika petani mengalami suatu keadaan yang menurutnya itu dapat merugikan atau mengancam kelangsungan hidupnya maka para petani menjual atau menggadaikan harta benda miliknya. Sedangkan nilai resiprositas 
timbul apabila ada sebagian dari anggota masyarakat yang menghendaki bantuan dari anggota yang lainnya (Febriani, 2017). Norma subsistensi juga timbul di kalangan petani garam ketika para petani garam mengalami suatu kondisi dimana pendapatannya belum cukup untuk memenuhi kebutuhan hidupnya dan keluarganya karena adanya beberapa faktor seperti fluktuasi harga garam,masalah perubahan cuaca, yang membuat para petani garam tidak bisa menggarap tambak. Sehingga para petani garam harus memutar otak untuk mencari solusi atau alternatif lain yang dapat mereka lakukan agar tetap dapat memenuhi subsistensinya.

Relasi Patron-Klien antara Pemilik Tambak dengan Petani Garam

Para petani garam dapat memanfaatkan hubungan patron klien sebagai bentuk etika subsistensi mereka. Hubungan patron klien sendiri mempunyai pengertian bahwa adanya pola hubungan timbal balik antara majikan dengan buruh, dalam hal ini antara pemilik tambak dengan petani garam yang mana menempatkan pemilik tambak sebagai patron dan petani garam sebagai klien. Scott (1983) menjelaskan bahwa patron klien adalah suatu kasus khusus hubungan antara dua orang yang sebagian besar melibatkan persahabatan instrumental, dimana seseorang yang kedudukan sosial ekonominya lebih tinggi (patron) menggunakan pengaruh dan sumber daya yang dimilikinya untuk memberikan perlindungan atau keuntungan kepada orang yang memiliki status sosial ekonomi yang lebih rendah (klien), yang mana pada gilirannya klien membalas pemberian tersebut dengan memberikan dukungan yang umum dan bantuan termasuk jasa-jasa kepada patron.

Hubungan antara petani garam dengan pemilik tambak ada yang memiliki ikatan kekerabatan atau keluarga, juga yang tidak memiliki ikatan kekerabatan. Hubungan patron klien yang tidak berdasar kekerabatan merupakan murni relasi kerja, yakni relasi antara majikan dengan bawahan (pekerja). Sedangkan relasi patronklien yang berdasarkan kekerabatan, menyangkut unsur kekerabatan atau kekeluargaan yang terdapat antara pemilik dengan petani garam.

Adanya hubungan keluarga atau saudara yang terjalin antara petani garam dengan pemilik tambak membuat petani garam tidak sungkan untuk meminta bantuan salah satunya dalam hal ekonomi kepada pemilik tambak. Relasi kekeluargaan inilah yang membuat pemilik tambak tak segan membantu petani garam yang mana hal tersebut selain memberikan keuntugan pada keduanya juga dapat menambah rasa persaudaraan dan menguatkan ikatan kekeluargaan diantara mereka

Meskipun begitu, hubungan kerja yang terjalin antara petani garam dengan pemilik tambak tetap merupakan hubungan antara patron dengan klien, walaupun terdapat hubungan kekerabatan antara petani garam dengan pemilik tambak, namun relasi patron klien antara pemilik tambak dengan petani garam tetap ada. Jika membahas mengenai hubungan kerja berarti membahas mengenai pranata sosial yang mengatur mengenai hak dan kewajiban antara patron dalam hal ini sebagai pemilik atau yang memberi pekerjaan dengan klien (penggarap tambak) agar kepentingan mereka dapat saling terpenuhi (Astuti, 1993) .

Terlepas ada atau tidak adanya ikatan kekerabatan antara pemilik tambak dengan petani garam, pemilik tambak harus tetap menjalin hubungan baik dengan petani garam agar proses produksi dapat berjalan dengan lancar. Dalam kaitannya dengan relasi patronklien antara pemilik tambak dan petani garam, Scott dalam Nurdin, dkk (2016) menyebut terdapat beberapa bentuk pertukaran yang dilakukan antara patron kepada klien antara lain yaitu:

1) Penghidupan subsistensi dasar, dengan adanya usaha penggaraman ini pemilik tambak sebagai patron 
memberikan lapangan pekerjaan kepada petani garam dengan tujuan untuk menambah pendapatan guna memenuhi kebutuhan subsistensinya.

2) Jaminan krisis subsistensi, pada umumnya dalam sebuah usaha seperti produksi garam, pemilik tambak sebagai patron diharapkan dapat memberikan jaminan kepada petani garam ketika terjadi kecelakaan kerja atau ketika petani garam mengalami sakit atau sedang kesulitan dalam hal ekonomi.

3) Makelar dan pengaruh, maksudnya di sini pemilik tambak selain menggunakan kekuatannya untuk melindungi petani garam, ia juga dapat menggunakan kekuatannya untuk meminta imbalan atau menarik keuntungan dari petani garam yaitu dengan meminta jasa dari petani garam untuk mau mengolah tambak miliknya atau yang lainnya.

Secara tidak langsung norma resiprositas timbul dalam relasi patronklien tersebut. Sederhananya resiprositas merupakan hubungan timbal balik antar individu atau antar kelompok (Hasan, 2018). Sedangkan menurut Hudayana (1991) konsep resiprositas berbeda dengan redistribusi. Jika aktivitas resiprositas harus memiliki hubungan simetris sebagai syaratnya, namun jika aktivitas redistribusi memerlukan hubungan asimetris sebagai syaratnya. Berbeda dengan pendapat dari Halperin dan Dow dalam Sairin (2002) dimana keberadaan resiprositas ditunjang oleh adanya struktur masyarakat yang egaliter, artinya suatu masyarakat yang ditandai dengan rendahnya tingkat stratifikasi sosial. Dengan adanya struktur masyarakat yang egaliter ini memberi kemudahan bagi masyarakatnya agar dapat menempatkan diri dalam kategori sosial yang sama ketika mengadakan kontak resiprositas (Pribadhi, 2011).

$$
\text { Pada dasarnya manusia }
$$

merupakan makhluk sosial yang membutuhkan bantuan orang lain untuk memenuhi kebutuhan hidupnya, oleh karena itu timbullah resiprositas dalam masyarakat. Begitupun yang terjadi pada petani garam di Desa Dresi Kulon, ketika petani garam mengalami kesulitan atau masalah, petani garam dapat meminta bantuan kepada pemilik tambak maupun keluarga ataupun anggota masyarakat yang lain.

"Pas istrine kulo kae badhe nglairke mbak kulo nge bon riyen kalih bose kangge biaya lairan... Lah mengko nyaure soko pendapatanne kulo sing dipotong... kuwi juga mboten nganggo jaminan opo-opo mbak, mok bose niku njaluk, penting kulo iku tetep kerjo nek tambak kuwi, bos e kuwi apikan tenan mbak dadi yo nak kulo arep pindah kerjo yo gak penak"

(Ketika istri saya mau melahirkan mbak saya ngebon dulu sama bos saya untuk biaya lahiran.lah nanti mengembalikanya dari pendapatan saya yang dipotong.itu juga tidak menggunakan jaminan apa-apa mbak, bosnya hanya minta yang penting saya tetap kerja ditambak itu. bos saya itu baik banget mbak jadi kalau saya mau pindah kerja ya nggak enak) (JN, 47 Tahun, Wawancara Pribadi, Jum'at 19 Juni 2020)

Dari apa yang disampaikan oleh JN di atas memperlihatkan bahwa terjadi resiprositas antara pemilik tambak dengan petani garam. Seperti yang dikatakan oleh Suryanegara \& Hikmah (2012) bahwa adanya hubungan timbal balik atau resiprositas menempatkan petani garam sebagai klien berada di bawah dominasi dan bayang-bayang "utang budi" dari pemilik tambak sebagai patronnya. Sikap pemilik tambak sebagai patron yang memberikan perlindungan kepada kliennya membuat petani garam merasa memiliki utang budi sehingga membuat petani garam tidak ingin mengecewakan pemilik tambak dengan tetap bekerja di tambak tersebut secara maksimal.

Secara tidak langsung pola hubungan relasi patron klien yang terjadi antara pemilik tambak dengan petani garam didasari atas rasa saling percaya dan juga saling menguntungkan, meskipun resiprositas 
diantara keduanya dalam bentuk yang berbeda. Pemilik tambak memberikan kepercayaan kepada petani garam dengan bersedia membantu petani garam jika mereka sedang kesulitan, dengan begitu petani garam merasa nyaman karena pemilik memberikan perlindungan sehingga petani garam tetap mau memberikan jasanya untuk menggarap tambaknya. Priyatna (2011) mengungkapkan bahwa pola relasi patron klien antara petani garam dengan pemilik tambak menjadi sebuah exit strategy yang dilakukan oleh petani garam dalam menghadapi krisis subsistensi. Dimana pemilik tambak menyediakan jaminan sosial ekonomi dan pekerjaan bagi petani garam, yang kemudian dibayar oleh petani garam sebagai klien dalam bentuk tenaga atau jasa dan kepatuhan terhadap pemilik tambak sebagai patronnya.

\section{Strategi Survival Petani Garam}

Para petani garam harus bisa tetap survive (bertahan hidup) dalam segala kondisi agar dapat melakukan aktivitas kehidupannya sehari-hari. Strategi bertahan hidup menurut Irwan dan Indraddin dalam Rizaldi (2017) merupakan salah satu alternatif yang dilakukan oleh petani garam guna membangun suatu kegiatan dalam rangka agar dapat meningkatkan taraf hidup dan dapat meningkatkan perekonomiannya. Senada dengan itu Snel dan Staring dalam Astutik, dkk (2019) juga menyatakan bahwa strategi bertahan hidup adalah rangkaian tindakan yang dipilih secara standar oleh individu dan rumah tangga menengah ke bawah secara sosial ekonominya. Oleh karena itu petani garam yang memiliki status sosial ekonomi ke bawah menggunakan strategi dengan cara-cara seperti dapat menambah penghasilan dengan menggunakan sumber-sumber yang lain, bisa juga dengan mengurangi pengeluaran baik dari segi kualitas maupun kuantitasnya.

$$
\text { James C. Scott (1983) }
$$

mengemukakan bahwa terdapat mekanisme survival yang dapat dilakukan oleh petani garam untuk tetap mempertahankan subsistensinya. Adapun mekanisme survival yang dikemukakan oleh James Scott antara lain yaitu memanfaatkan relasi atau jaringan sosial, mengikat sabuk lebih kencang, atau menggunakan alternatif subsistensi.

1) Memanfaatkan relasi atau jaringan sosial

Mekanisme bertahan hidup dengan memanfaatkan relasi atau jaringan sosial di kalangan petani garam dengan cara meminta bantuan kepada relasi atau jaringan yang mereka miliki seperti keluarga, teman, atau bahkan patron mereka. Menurut Dharmawan (2018) strategi ini menjadi salah satu modal sosial yang dapat dilakukan oleh petani garam sebagai sarana untuk bertukar informasi mengenai diversifikasi pekerjaan dan dalam aktivitas hutang piutang. Terkait dengan aktivitas hutang piutang Dara (2017) mengungkap bahwa masyarakat lapisan bawah menganggap hutang sebagai segala sesuatu yang wajar dilakukan oleh manusia yang tidak mampu memenuhi kebutuhannya akibat sumber daya finansisal yang rendah.

Hal tersebut menunjukkan bahwa mempunyai relasi atau jaringan sosial itu sangat penting apalagi dikalangan petani kecil karena dengan adanya relasi tersebut dapat dijadikan sebagai bentuk asuransi dikalangan petani. Menurut Safitri dan Ekawati (2013) adanya jaringan sosial merupakan faktor penting dalam kehidupan manusia, karena jaringan sosial sangat berpengaruh bagi seseorang terutama ketika orang tersebut sedang membutuhkan bantuan. Dalam kondisi seperti inilah adanya relasi atau jaringan sosial sangat dibutuhkan baik itu formal maupun informal. Ini juga dilakukan oleh para petani garam di Desa Dresi Kulon dimana mereka dapat meminta bantuan kepada relasi yang mereka miliki entah itu dengan meminjam uang atau meminta bantuan yang lain. 
Meminta bantuan seperti meminjam uang itu merupakan sesuatu hal yang dapat dikatakan sudah biasa apalagi pada masyarakat pedesaan, karena sistem kekerabatan masyarakat pedesaan yang lebih erat dibandingkan dengan masyarakat perkotaan yang cenderung lebih homogen. Sehingga dengan memiliki jaringan sosial menjadi keuntungan tersendiri khususnya bagi para petani kecil dalam hal ini adalah para petani garam atau penggarap tambak karena mereka dapat meminta bantuan ketika mereka sedang mengalami kesulitan khususnya dalam hal pemenuhan kebutuhan subsistensi mereka.

Selain itu untuk memenuhi kebutuhan rumah tangga biasanya keluarga petani, khususnya istri petani garam, melakukan kredit barangbarang seperti perkakas rumah tangga sampai pakaian. Seperti yang diungkapkan oleh Geertz dalam (Handayani, 2015) yang menyatakan bahwa kredit itu memungkinkan seseorang untuk mendapatkan uang atau barang yang dikehendaki, dalam hal ini uang sebagai alat bayar dalam transaksi berkredit yang dilakukan antara kreditor dan nasabah kredit. Hal tersebut juga dilakukan oleh istri petani garam karena mereka tidak mempunyai uang untuk membeli barang-barang tersebut secara langsung. Sehingga dengan melakukan kredit barang dirasa dapat memudahkan dan meringankan mereka agar mempunyai barangbarang seperti peralatan rumah tangga maupun pakaian.

Biasanya istri petani garam akan mengajukan kredit pada renternir, tentu saja disertai dengan bunga, yang juga harus dibayar oleh petani. Sebelumnya terdapat perjanjian terlebih dahulu antara istri petani garam dengan rentenir tersebut mengenai waktu dan jumlah pembayaran. Biasanya mereka membayar cicilan sebesar Rp 1.000 sampai $\mathrm{Rp} 5.000$ setiap harinya atau setiap seminggu sekali tergantung perjanjian sebelumnya. Rentenir setiap hari atau seminggu sekali mendatangi rumah petani garam untuk menagih pembayaran.

Mengkredit barang yang biasa dilakukan oleh ibu rumah tangga di pedesaan dikenal juga dengan istilah mindring pada beberapa masyarakat yang ada di Jawa. Solikatun, dkk (2015) berpendapat bahwa munculnya mindring dilatar belakangi oleh para ibu rumah tangga yang tidak memiliki cukup uang untuk memperoleh atau membeli barang-barang di pasar. Oleh karena itu dengan adanya mindring ini para ibu rumah tangga dalam hal ini adalah para istri petani garam merasa terbantu agar dapat keluar dari masalah ekonomi mereka. biasanya tukang mindring menggunakan sistem jemput bola dalam menawarkan jasanya kepada masyarakat. Artinya tukang mindring tersebutlah yang mendatangi calon nasabahnya agar mau mengkredit barang kepadanya. Di sini para nasabah diperbolehkan untuk mengkredit barang apa saja tanpa memberikan uang muka. Kemudian juga dalam sistem pembayaran cicilan tersebut tanpa batas minimal dan jangka waktu yang membuat para ibu rumah tangga tidak merasa keberatan.

2) Mengikat sabuk lebih kencang (alternatif subsistensi)

Scott (1983) menyatakan bahwa yang dimaksud dengan mengikat sabuk lebih kencang yaitu mengurangi biaya anggaran belanja terutama untuk makan mereka atau dengan kembali ke pola subsisten, yaitu dengan mencari lauk pauk untuk makanan dari bahanbahan yang ada di sekitar mereka. Jika mereka memiliki sawah atau kebun bisa juga dengan memanfaatkan hasil perkebunan atau sawah yang mereka miliki (Nugraha, 2015). Selaras dengan yang diungkap oleh Pertiwi dan Nurhamlin (2014) bahwa strategi pasif merupakan cara yang dapat dilakukan oleh petani dengan mengurangi pengeluaran keluarga dengan pendekatan yang pasif dengan cara memperkecil pengeluaran.

Dengan begitu para petani tidak perlu lagi mengeluarkan biaya untuk 
membeli bahan makanan sehingga dapat menghemat pengeluaran mereka. Hal tersebut juga diterapkan oleh para petani garam yang ada di Desa Dresi Kulon, dimana para petani garam yang memiliki sawah dapat memanfaatkan hasil dari sawah yang mereka miliki yaitu berupa padi untuk memenuhi kebutuhan makan mereka, seperti pernyataan dari JD seorang petani garam:

"Nggih mbak, kan kulo gadah sawah piyambak, lah nak pas rendeng ngoten niki kulo ngurusi sawahe niku mbak, nak pas panen gabah e niku nggih sebagian disade sebagian di selepke kanggo awak dewe mbak"

(lya mbak, itu saya kan punya sawah sendiri, lah kalau pas musim hujan begini saya mengurus sawah itu mbak, kalau pas panen padinya itu sebagaian dijual sebagian lagi digiling untuk diri sendiri mbak) (JD, 58 tahun, Wawancara pribadi, Rabu 3 Juni 2020).

Dari pernyataan yang disampaikan oleh JD di atas bahwa sebagian hasil panen padi yang diperoleh dijual dan sebagian lagi dimanfaatkan untuk memenuhi kebutuhan hidupnya sehari-hari. JD dengan demikian tidak harus mengeluarkan uang untuk membeli beras sehingga dapat menghemat dan mengurangi pengeluaran belanja keluarganya.

Selaras dengan yang diungkap oleh Hardianto (2016) bahwa di berbagai wilayah pedesaan sudah bukan menjadi rahasia lagi bahwa akses pada lahan untuk produksi yang subsisten sedikit banyak akan melindungi rumah tangga petani dari biaya yang mengikat yaitu dengan menyediakan suatu bentuk jaminan pangan yang penting. Memanfaatkan hasil panen dari sawah yang dimiliki memang sudah biasa dilakukan oleh para petani di pedesaan termasuk petani garam di Desa Dresi Kulon. Selain untuk digunakan sendiri hasil panen para petani juga dijual yang mana hasil dari penjualan padi tersebut dapat digunakan untuk memenuhi kebutuhan yang lain seperti membayar tagihan ataupun yang dapat mereka simpan untuk memenuhi kebutuhan hidup dihari-hari berikutnya.

Mengikat sabuk lebih kencang dapat dikatakan sebagai bentuk strategi pasif, yang mana strategi pasif merupakan strategi bertahan hidup yang dilakukan oleh petani kecil dalam hal ini yaitu petani garam dengan menerapkan hidup hemat. Sikap hemat yang dilakukan oleh petani garam sebagai petani kecil yaitu dengan membiasakan keluarganya untuk hidup dengan keadaan seadanya seperti makan seadanya dan tinggal di rumah yang sederhana. Mengingat pendapat yang diterima oleh petani garam yang terbilang rendah. Sehingga petani membiasakan diri untuk makan dengan lauk yang sederhana dan seadanya (Abidin, 2015).

Mengikat sabuk lebih kencang dapat dikatakan sebagai jalan terakhir dari mekanisme survival yang dapat dilakukan oleh petani garam karena mekanisme survival lainnya tidak dapat mereka lakukan. Artinya, ketika petani garam tidak memiliki alternatif lain seperti memiliki pekerjaan sampingan dan mereka enggan untuk meminta bantuan kepada relasi atau jaringan yang mereka miliki, maka satu-satunya cara yaitu dengan jalan berhemat. Pada dasarnya petani garam mempraktikkan mekanisme-mekanisme survival itu untuk membantunya dalam mempertahankan kehidupan subsistensinya.

\section{SIMPULAN DAN SARAN}

Petani garam tradisional di Desa Dresi Kulon Kecamatan Kaliori Kabupaten Rembang mayoritas masih menggunakan alat-alat tradisional atau manual dalam proses produksi garam. Dinamika kehidupan petani garam tradisional tidak bisa dilepaskan dari proses produksi garam yang mengalami kendala utama pada cuaca yang sering tidak menentu. Permasalahan lainnya adalah banyaknya impor garam oleh 
pemerintah, dan harga jual garam yang menurun karena melimpahnya hasil panen. Kendala-kendala dalam produksi garam tersebut menyebabkan terjadinya perubahan dalam matapencaharian petani garam karena harus menyesuaikan dengan keadaan sehingga mereka tetap dapat mempertahankan hidupnya.

Petani garam tradisional di Desa Dresi Kulon menggunakan prinsip mekanisme survival sebagai bentuk strategi atau cara yang dapat mereka lakukan untuk tetap dapat bertahan hidup dalam kondisi yang minimal. Mekanisme survival merupakan bagian dari teori moral ekonomi petani yang dikemukakan oleh James C. Scott antara lain, pertama menggunakan relasi atau jaringan sosial, dimana petani garam dapat meminta bantuan ketika mereka mengalami kesulitan khususnya dalam hal pemenuhan kebutuhan hidupnya biasanya mereka akan berhutang kepada patron yaitu pemilik tambak atau kepada saudara mereka. Kedua yaitu menggunakan alternatif subsistensi, dimana petani garam beralih profesi ketika proses produksi garam tidak dapat dilakukan yaitu dengan bekerja sebagai nelayan, tukang ojek, dan petani sawah. Ketiga yaitu mengikat sabuk lebih kencang, dimana petani garam dapat mengurangi biaya pengeluaran mereka dengan cara berhemat. Petani garam yang memiliki sawah biasanya memanfaatkan sebagian hasil panennya yang dikonsumsi bersama keluarga daripada mereka harus membeli ke warung. Selain itu mereka juga mengurangi uang jajan anak, dan mengurangi kualitas makan dengan makan yang sederhana seperti tempe dan tahu.

Petani garam harus bisa lebih inovatif dan kreatif dalam memproduksi garam sehingga produksi garam dapat meningkat baik dari segi kualitas dan kuantitas agar dapat bersaing dengan garam impor. Pemerintah daerah seyogyanya lebih peduli dan memberikan perhatian lebih pada produksi dan para pelaku usaha produksi garam lokal terutama para petani penggarap. Selain itu pemerintah juga harus mengupayakan untuk mengimbangi masuknya impor garam dengan hasil produksi garam lokal agar tidak terjadi kesenjangan yang menyebabkan menurunnya harga garam lokal, yang mana hal tersebut niscaya merugikan petani garam dan pemilik tambak.

\section{DAFTAR PUSTAKA}

Abidin, Z. A. (2015). Strategi Bertahan Hidup Petani Kecil Di Desa Sindetlami Kecamatan Besuk Kabupaten Probolinggo. Jurnal Pendidikan Ekonomi, IX(2).

Andriyani, R. P. (2013). Analisis Usaha Tambak Garam Di Desa Gedongmulyo Kecamatan Lasem Kabupaten Rembang. Jurnal Perikanan (J. Fish), XV(2).

Astuti, W. A. (1993). Hubungan Kerja Petani - Buruh Tani Di Pedesaan Dan Faktor Yang Mempengaruhinya. Jurnal Forum Geografi, 7(12).

Astutik, J. T. (2019). Strategi Survival Perempuan Penyandang Disabilitas Sebagai Kepala Keluarga (Study Pada Perempuan Penyandang Disabilitas Di Desa Kabuh, Kecamatan Kabuh, Kabupaten Jombang). Jurnal Perempuan Dan Anak (JPA), 2(2).

Baiquni, M. (2007). Strategi Penghidupan Di Masa Krisis. Yogyakarta: Ideas Media.

Chiari, A. (2015). Strategi Bertahan Hidup Petani Saat Musim Kemarau (Studi Pada Petani Sayur Desa Tulungrejo, Kecamatan Bumiaji, Kota Batu). Jurnal Mahasiswa Sosiologi, 2(4).

Dara, U. D. (2017). Hutang Piutang Di Kalangan Buruh Perempuan Di Desa Jetis, Kecamatan Jetis, Kabupaten Mojokerto. Surabaya: Universitas Airlangga Surabaya. 
Dharmawan, D. S. (2018). Strategi Bertahan Hidup Petani Garam Di Desa Pinggirpapas Kecamatan Kalianget Kabupaten Sumenep. Malang: Universitas Muhammadiyah Malang.

Farahdina, S. N. (2016). Analisis Pengaruh Pengalaman Bekerja, Pendidikan, Dan Program Pemberdayaan Usaha Garam Rakyat (PUGAR) Terhadap Pendapatan Petani Garam. Semarang: Universitas Diponegoro.

Fauzin. (2019). Analisis Pengaturan Perlindungan Petambak Garam Di Kabupaten Sampang Dalam Kebijakan Tata Kelola Garam. Jurnal Pamator, 12(2).

Febriani, D. (2017). Strategi Bertahan Hidup Petani Penggarap Di Jorong Sarilamak Nagari Sarilamak Kecamatan Narau Kabupaten Lima Puluh Kota. Jurnal Jom FISIP, 4(1).

Handayani, S. A. (2015). Berkayuh Diantara Dua Arus: Persepsi Masyarakat Madura Dan Jawa Tentang Uang, Utang, Dan Kredit. Jember: Universitas Jember.

Hardianto, A. D. (2016). Mekanisme Survival Keluarga Nelayan (Studi Terhadap Nelayan Di Kelurahan Kenjeran, Kecamatan Bulak, Kota Surabaya. Jurnal Universitas Airlangga.

Haryatno, D. P. (2012). Kajian Strategi Adaptasi Budaya Petani Garam. Jurnal Komunitas, 4(2).

Hasan, S. (2018). Patron Klien Dalam Lingkungan Masyarakat Petani Di Desa Kampala Kabupaten Jeneponto. Makasar: Universitas Negeri Makassar.

Hudayana, B. (1991). Konsep Resiprositas Dalam Antropologi Ekonomi. Jurnal Humaniora, (3).

Ichsannudin, S. P. (2016). Strategi Pemberdayaan Ekonomi Petani Garam Melalui Pendayagunaan Aset Tanah Pegaraman.
Economics Development Analysis Journal , 5(4).

Masruroh, A. a. (2020). Tradisi Jual Gadai Warisan Pohon Jambu Air (Strategi Bertahan Hidup (Life Survival Strategy) Masyarakat Desa Taddan, SampangMadura). Jurnal Sosialisasi, 7(2).

Miles, M. B. (2014). Qualitative Data Analysis: A Methods Sourcebook. USA: Sage Publications.

Nikmaturohmah, L. (2016). Analisis Pemasaran Garam Di Kecamatan Kaliori Kabupaten Rembang. Jurnal AGRISTA.

Nugraha, H. S. (2015). Strategi Bertahan Hidup Petani Di Kelurahan Made Surabaya. Jurnal Unair, 4(3).

Nurdin, I. P. (2016). Dilema Hubungan Patron Client Di Komunitas Petani Garam. Jurnal Komunikasi Pembangunan, 14(2).

Pertiwi, K. P. (2014). Strategi Bertahan Hidup Petani Penyadap Karet Di Desa Pulau Birandang Kecamatan Kampar Timur Kabupaten Kampar. Jurnal Online Mahasiswa (JOM) Bidang IImu Sosial Dan Ilmu Politik, 1(2).

Pribadhi, P. A. (2011). Resiprositas Dalam Kehidupan Sosial Ekonomi Masyarakat (Studi Kasus Pada Masyarakat Kelurahan Kauman Kabupaten Blora). Semarang: Fakultas IImu Sosial Universitas Negeri Semarang.

Priyatna, F. N. (2011). Pola Pemanfaatan Sumber Daya, Subsistensi Dan Pola Hubungan Patron-Klien Masyarakat Nelayan Danau Tempe, Sulawesi Selatan. Jurnal Matematika, Sains Dan Tekonologi, 12(1).

Rizaldi, A. (2017). Budaya Kemiskinan Masyarakat Pesisir Di Sekitar Waduk Pluit Kelurahan Penjaringan Jakarta Utara. Jakarta: UIN Syarif Hidayatullah Jakarta. 
Rochwulaningsih, Y. (2007). Petani Garam Dalam Jeratan Kapitalisme: Analisis Kasus Petani Garam Di Rembang Jawa Tengah. Jurnal Paramita, 20(3):228-39.

Rochwulaningsih, Y. (2012). Pendekatan Sosiologi Sejarah Pada Komoditas Garam Rakyat: Dari Ekspor Menjadi Impor. Jurnal Paramita, 22(2).

Safitri, Y. M. (2013). Jaringan Sosial Dan Strategi Adaptasi Tenaga Kerja Migran Asal Lampung Di Desa Jaya Mukti Kecamatan Cikarang Pusat, Kabupaten Bekasi Provinsi Jawa Barat. Jurnal Sosiologi Pedesaan, 1(1).

Salim, Z. a. (2016). Info Komoditi Garam. Jakarta: Badan Pengkajian dan Pengembangan Perdagangan Kementrian Perdagangan $\mathrm{RI}$ bekerjasama dengan Al Mawardi Prima Anggota IKAPI DKI Jaya.

Scott, J. C. (1983). Moral Ekonomi Petani: Pergolakan Dan Subsistensi Di Asia Tenggara. Jakarta: LP3ES.

Solikatun, D. T. (2015). Perilaku Ibu Rumah Tangga Pemakai Kredit Barang Keliling (Mindring): Studi Kasus pada lbu Rumah Tangga Pemakai Kredit Barang Keliling Mindring) di Dukuh Pundung Tegal Sari Desa Manjung Kecamatan Sawit Kabupaten Boyolali. Jurnal Analisa Sosiologi, 4(2): 60-74.

Suryanegara, E. a. (2012). Hubungan Patron Klien Pada Usaha Budidaya Udang Windu (Penaeus Monodon) Dan Bandeng (Chanos Chanos) Di Kabupaten Indramayu, Jawa Barat. Jurnal Buletin Riset Sosek Kelautan Dan Perikanan, 7(2).

Syafi'i, A. (2006). Potret Pemberdayaan Petani Garam, Implementasi Konsep Dan Strategi. Surabaya: Untag Press.
Zakki, N. a. (2016). Faktor-Faktor Yang Mempengarhi Pendapatan Dan Kesejahteraan Petani Garam Rakyat Kawasan Pesisir Kalianget. Jurnal Performance, 6(1). 